\title{
Corporate Governance and Initial Public Offerings in Switzerland
}

Winfried Ruigrok and Dimitrios Georgakakis

\section{SOURCE:}

Ruigrok W. and Georgakakis D.G. 2012. Corporate governance and initial public offerings in Switzerland, In W. Judge and A. Zattoni, (ed.), Corporate Governance and Initial Public Offerings: An international Perspective, pp. 449-469, Cambridge University Press, Cambridge, UK.

\section{INTRODUCTION}

Switzerland is an interesting country to study the dynamics of Initial Public Offerings (IPOs) because it offers two paradoxes. Understanding the backgrounds of these paradoxes helps to appreciate the nature of the Swiss corporate governance system, and the direction that this system may take as a result of recent IPO activity. First, Switzerland has recently been ranked as the most competitive country in the world (World Economic Forum, 2010: 14). Specifically, its position as second in the world in terms of "innovation and sophistication factors" suggests that Switzerland may be the home of a large number of IPOs. However, over the period 2006-2008, only 16 IPOs were registered in Switzerland that met the IPO definition that is used in this volume.

Second, located in the heart of Europe with a population of 7.6 million people, Switzerland is the home of many leading multinational corporations (MNCs) such as Nestlé, Novartis, Roche, Zurich Financial Services, UBS and Credit Suisse. Indeed, with almost two Fortune Global 500 firms per 1 million Swiss citizens, Switzerland has the highest density of Fortune Global 500 firms in the world. Furthermore, Switzerland has also been the object of largescale foreign direct investments by non-Swiss MNCs keen to relocate headquarter-type activities to Switzerland. However, efforts to raise the attractiveness of Switzerland to foreign institutional investors have been less than successful and foreign investors have thus far played a modest role in the Swiss corporate governance scene.

Similar to countries like Austria, Germany and Japan, Swiss listed companies operate under Germanic civil law. The Swiss governance system is often categorized as belonging to the 
Continental European model of corporate governance. Indeed, Swiss listed firms have traditionally been characterized by comparatively high rates of ownership concentration. Today, major block-holders tend to be large corporations and family owners rather than banks. Bank ownership in Swiss listed firms has been significantly reduced during the last few years.

However, the Swiss corporate governance scene differs from other Germanic civil law economies in two key respects. First, Swiss listed firms are free to adopt a board structure that best fits their business requirements, i.e. they can establish either a one-tier or a two-tier board. The only category of Swiss listed firms that have no choice in terms of board structure are banks which are required by law to set up a two-tier board. Second, most corporate governance regulations of the Swiss code are based on the "comply or explain" principle. However, the Swiss Stock Exchange (SIX) has drafted additional requirements stipulating that all listed firms have to publish specific corporate governance details (such as total executive remuneration, board composition, share ownership and financial performance information) in their annual reports.

In the past, Switzerland has occasionally been criticized for inadequate investor protection standards (World Bank, 2010), high ownership concentration (OECD, 2006) and a lack of response to international pressures for a more shareholder oriented model of governance (US Commercial Service, 2009). In response to such criticism, Switzerland has over the years introduced a series of corporate governance reforms aiming to enhance convergence with international governance standards (Schweizer, 2006; Schleiffer and von Planta, 2009; Ruigrok and Canepa, 2005). For Switzerland, it is essential to adopt governance guidelines that correspond with what are perceived as international best practices and to transform the governance system in a way that is in line with more dispersed ownership, in order to be an attractive investment location for foreign investors.

The importance of attracting institutional investors from both inside and outside the country is particularly crucial for newly listed IPO firms. The risk of investing in IPO firms is higher than it is in large already listed companies, since IPOs are usually young firms that lack of long operating history and publicly available performance information (Certo, 2003). IPO firms that manage to attract foreign investors may broaden their investment base and have a higher likelihood to attract specialized investors that understand the IPO firm's business. 
Thus, adopting efficient corporate governance principles that meet foreign investors' preferences and promote ownership dispersion is crucial for (Swiss) IPO success.

The present chapter describes the current state of corporate governance in Switzerland following the most recent governance reforms introduced in 2007. Subsequently, it explains the Swiss IPO process and by using a sample of all Swiss IPOs between 2006 and 2008, it investigates whether newly listed firms tend to follow the recommended corporate governance principles and whether ownership concentration in these firms continues to be high. Descriptive statistics show that IPO firms in Switzerland tend to adopt the established corporate governance guidelines. This suggests that Swiss IPO firms and, in extension, the Swiss governance system are increasingly falling in line with international governance standards. Despite this positive picture, however, ownership concentration in Swiss IPOs still remains high.

\section{The Swiss code of best practice}

The first Swiss corporate law, also known as "Code of Obligations" (CO), came into effect in July 1992 with the purpose to maximize shareholders' value, to serve stakeholders' interests and to attract foreign and domestic investors. The year 2002 signaled radical reforms for the Swiss governance system; the Swiss Business Federation (Economiesuisse) presented the Swiss Code of Best Practice for Corporate Governance (Swiss Code) with guidelines applicable to all companies listed on the Swiss Exchange (SWX; today SIX). This code was established on a voluntary basis with the aim of protecting minority shareholders' rights and clarifying the responsibilities of the board of directors (Economiesuisse, 2007). In parallel, the Swiss Exchange introduced a Directive on Information Relating to Corporate Governance (DCG) by providing mandatory principles for companies listed at the SWX with the purpose to increase transparency and accountability of issuers.

The most recent updates on the "Swiss Code" were made in 2005 and 2007. Emphasis was given to further enhance convergence between the Swiss system and the international corporate governance principles. According to Schweizer's report (2006: 57), "the Swiss reforms enacted in 2005 demonstrate an increasing global convergence of some basic corporate governance standards, such as external audit and auditor supervision, internal control, risk management, as well as transparency requirements for companies". The reforms were greatly influenced by the development of the Sarbanes-Oxley Act in the USA. In 2007, 
however, the International Monetary Fund (IMF) claimed that Swiss regulatory bodies should "further strengthen the comparability of financial information disclosed to investors, and introduce proper supervision and sanctioning of auditors and listed companies” (IMF, 2007: 13). As a quick response to that, the Swiss Business Federation (Economiesuisse) introduced some further reforms to the Swiss code during the same year. Changes mainly referred to the remuneration of directors and senior managers, the reinforcement of shareholder rights, as well as other internal control issues (Economiesuisse, 2007). To shed more detailed light on the Swiss governance system, the following paragraphs present the major characteristics of the "Swiss code of best practice" with regards to the rights of shareholders, the responsibilities and composition of the board of directors based on the most recent reforms introduced in 2007.

Shareholder rights: The most important process of corporate governance is the general shareholders' meeting which is compulsory for all listed companies at least once a year. During the meeting, shareholders can make suggestions on the items given in the meeting's agenda and ask the board of directors to provide detailed information concerning company matters. Shareholders can make decisions regarding personnel issues at the top level of the organization, such as appointing auditors and electing new board members (Economiesuisse, 2007). To put an additional subject on the meeting's agenda, a shareholder must own shares with a nominal value of at least 1.06 million $^{1}$ (USD) (CO, art. 699). Furthermore, shareholders with more than 10 percent of registered shares have the right to call for additional general meetings (CO, art. 699). Such shareholder powers have led some scholars to characterize the Swiss system as the most shareholder oriented system of the "European continental governance block” (Pedrazzini, 1998). However, other studies argue that further reforms with regards to the protection of minority shareholders are required in order to enhance convergence with the international governance standards (Mach et al., 2007).

Board structure and composition: According to the Swiss code of best practice, listed firms are required to have a board of directors responsible for the executive control and management of the organization. All firms, apart from banks, have the flexibility to structure their boards based on their business requirements. There are three board structures that Swiss listed firms can have: a) the unitary board structure (the board of directors has the responsibility for both control and management of the organization) b) the dual board

\footnotetext{
${ }^{1}$ Amounts converted from CHF to USD as of 31/12/2010.
} 
structure (two-tier boards) and c) the mixed board structure (boards that consist of both executive and non-executive members). Banks, however, must consist of two-tier boards; the supervisory board that is responsible for monitoring executive behaviors and actions, and the executive board responsible for the adequate management of the organization (Economiesuisse, 2007).

In case of a mixed board structure, the Swiss Code recommends that the majority of board members should be non-executive independent directors. In Switzerland, the definition of directors' independence differs from most countries. According to the Swiss code, directors are characterized as independent if they have no personal and/or professional relationship with the focal firm for three years before their appointment. This differs from the more widely accepted five year period (such as in the USA and the UK). Furthermore, Swiss listed firms are free to determine whether the roles of the CEO and Chairperson should be separate or combined (duality). Finally, another recommendation concerning the composition of Swiss boards is about the nationality of directors. The Swiss code recommends that boards of Swiss firms that operate abroad should consist of members who have "long-standing international experience" and/or who are foreign nationals (not Swiss). The purpose of this recommendation is to enhance the attractiveness of Swiss companies to foreign institutional investors (Economiesuisse, 2007). No gender quota stipulations exist, despite the even by international standards very low female board participation ratio (Ruigrok, et al., 2007).

Board responsibilities and committees: The Swiss Code implies that the main responsibilities of boards of directors in Swiss listed firms are: a) defining the strategic goals and the means to achieve them, b) supervising and monitoring the executive management, c) preparing the annual report as well as the agenda of the general shareholders' meeting, d) appointing and/or removing executive members and e) actively representing the company inside and outside the organizational context (CO art. 716a). To fulfill these responsibilities effectively, boards should meet at least four times a year in order to discuss important company matters and to evaluate the performance of executive members. Additionally, the compensation of all members of the supervisory and executive board, as well as the characteristics of shareholders with more than 5 percent of shares should be reported in the firm's annual report. Finally, the Swiss Code recommends that boards of directors should set up audit, nomination and compensation committees. These committees should consist of a majority of independent directors who have a relationship of no more than three years with the company and who have no family ties with any member of the executive management (Economiesuisse, 2007). 


\section{Swiss exchange and ownership concentration}

The Swiss exchange (SIX) was established in 1995 after the merger of Switzerland's three stock exchanges (stock exchanges of Geneva, Basle and Zurich). The number of companies listed in the SIX decreased from 263 in 2007 to 229 in 2009. This decrease in the number of Swiss listed companies between 2007 and 2009 may be a reflection of the global financial crisis that occurred since 2008. According to Deloitte's Swiss Stock Exchange Analysis report (2009), the Swiss Performance Index (SPI) declined by a total of 45 percent between June 2007 and March 2009. This decline in the SPI index is relatively low compared to the Dow Jones Industrial Average (DJIA) index which dropped 53 percent during the same period. In addition, other key economic indicators show that the Swiss economy experienced only a 1.5 percent GDP decrease at the year end 2009, which is also low compared with other economies like the European (EU) economy (-4.1 percent), the Japanese economy (-5 percent) and the USA economy (-2.4 percent) (Deloitte, 2010). The SPI declined due to the weight of the Swiss financial services industry. Yet, while the Swiss financial services industry suffered from the financial crisis, a healthy and export-oriented manufacturing sector at the same time benefited from robust demand in emerging markets even despite a strong Swiss franc (CHF).

Concerning corporate governance in Swiss listed companies, recent studies have shown that average board size is 7 board members. The majority of directors in Swiss listed firms are outside directors (89\%) while only a smaller proportion of them can be regarded as independent (58\%) based on the Swiss definition of board independence. Furthermore, the presence of female directors in Swiss listed firms has been relatively low (average 0.37 directors) while the majority of listed firms (57\%) have established the three recommended board committees (Hu, 2009; Ruigrok, et al., 2006; Keller, 2003). In 2003 Switzerland had the second highest ownership concentration rate among nine Western European countries (Table 1). Specifically, 47 percent of Swiss listed firms had one block-holder possessing more than 50 percent of shares (OECD, 2006). This high ownership concentration undermines the attractiveness for foreign (institutional) investors to invest in Swiss companies. However, efforts have been made to increase transparency about ownership dispersion rates. Based on the 2007 corporate governance reform, Swiss listed firms must report the shareholders who hold more than 5 percent of shares in their annual reports (Economiesuisse, 2007). 
Table 1: Share ownership in Swiss listed firms

$\begin{array}{lll}\begin{array}{l}\text { One shareholder with } \\ \text { over 50\% of stake }\end{array} & \begin{array}{l}\text { At least one } \\ \text { shareholder with stake } \\ \text { between } 25 \% \text { and } 50 \%\end{array} & \text { with over 25\% of stake }\end{array}$

\begin{tabular}{llll}
\hline Belgium & 59.46 & 21.62 & 18.92 \\
\hline Switzerland & $\mathbf{4 7 . 3 7}$ & $\mathbf{1 7 . 5 4}$ & $\mathbf{3 5 . 0 9}$ \\
\hline France & 41.10 & 32.19 & 26.71 \\
\hline Germany & 41.11 & 27.78 & 31.11 \\
\hline Denmark & 29.69 & 34.38 & 35.94 \\
\hline Netherlands & 17.86 & 20.24 & 61.90 \\
\hline Norway & 15.79 & 47.37 & 36.84 \\
\hline Sweden & 11.11 & 37.78 & 51.11 \\
\hline United Kingdom & 5.84 & 12.34 & 81.82 \\
\hline Source: OECD (2006) & & &
\end{tabular}

\section{IPO ACTIVITY IN SWITZERLAND (2006-2008)}

\section{The IPO process in Switzerland}

At the very beginning of the IPO process, the issuer should find a "recognized sponsor" (i.e. listing agent) that will act as representative of the IPO firm. Once the listing agent has been identified, the next step of the IPO is to fix the offering price which is determined by "bookbuilding”. During the "book-building" procedure the IPO firm offers a price at which investors can bid. At the same time, investment banks are getting information about the firm and try to find potential institutional investors. This helps the underwriter to fix the final offer-price and to create a list of potential investors (SIX Listing Rules, 2006; Ernst \& Young, 2008). Once the final price has been determined, Swiss IPOs should publicly provide an offering prospectus that includes the following information: a) the number of shares offered and the price for each share, b) the amount of expected proceeds during the first year of listing, c) information about prior financial record of the firm, d) major shareholders and their stakes prior to and after the offering and e) detailed information regarding the composition of 
the board of directors and executive team. The IPO prospectus should be reviewed by the respective listing agent and receive a formal approval from the Swiss Exchange (SIX, 2010).

To receive the final listing-admission, IPO firms need to fulfill specific standards depending on the segment in which they intend to be listed. As Table 2 shows, there are two alternative segments; the first (i.e. main standard) refers to firms that want to have access to foreign markets and satisfy the needs of foreign institutional investors, while the second segment (i.e. domestic standard) refers to firms that are only interested to attract domestic investors and/or do not yet fulfill the requirements of getting listed under the main standards. Firms going public under the main standards must have a minimum capital of 26,5 million (USD) and a free float (the number of freely tradable shares in circulation) of at least 25 percent. On the other hand, the minimum standards for the domestic track are substantially lower with a minimum capital of 2,6 million (USD) and 20 percent minimum free float $^{2}$. After the admission, firms have to follow the recommended corporate governance practices and to publicly report their performance at least twice a year.

Table 2: Listing requirements in Switzerland

\begin{tabular}{|l|l|l|}
\hline \multicolumn{1}{|c|}{ Main Standard } & \multicolumn{1}{|c|}{ Domestic Standard } \\
\hline $\begin{array}{l}\text { Financial } \\
\text { track record }\end{array}$ & At least 3 years track record & At least 2 years track record \\
\hline $\begin{array}{l}\text { Minimum } \\
\text { capital }\end{array}$ & At least 26,5 million USD & At least 2,6 million USD \\
\hline Free float & Minimum 25\% & Minimum 20\% \\
\hline $\begin{array}{l}\text { Market } \\
\text { capitalization }\end{array}$ & At least 26,5 million USD & At least 5,3 million USD \\
\hline $\begin{array}{l}\text { Accounting } \\
\text { Standards }\end{array}$ & IFRS/US GAAP & $\begin{array}{l}\text { Swiss GAAP ARR/IFRSUS } \\
\text { GAAP }\end{array}$ \\
\hline
\end{tabular}

Source: SIX, 2010

\section{IPO activity between 2006 and 2008}

During the period 2006 to 2008, a total number of 28 firms went public on the Swiss stock exchange (SIX). In line with EurIPO (2006), a Swiss IPO was defined as: 1) a firm that made

\footnotetext{
${ }^{2}$ Amounts converted from CHF to USD as of 31/12/2010.
} 
a new issue of a common stock (not a new issue of a debt instrument), 2) a firm that was not listed in any other stock exchange before its public offering at SIX. From the total number of 28 newly listed firms indicated at SIX website, the study excluded those that did not fulfill the above criteria. In addition, all firms that went public after spin-off activities were kept out of the sample since such firms cannot be regarded as "truly new" public offerings (Carpenter et al., 2003). This resulted in a final sample of sixteen Swiss IPOs (Table 3) belonging to five different industrial sectors based on the ICB classification. The three industrial sectors with the highest number of IPOs between 2006 and 2008 were: financials (35 percent), industrials (29 percent) and technology (18 percent). The dominant listing agent was Credit Suisse (24 percent of IPOs) followed by Zurich Cantonal Bank and UBS (18 percent and 12 percent of IPOs respectively). These three agents handled 54 percent of IPOs between 2006 and 2008. The year 2007 was the "hottest IPO year" of the study period with 8 IPOs, followed by 2006 with 6 IPOs and lastly 2008 with only 2 IPOs. The low number of IPOs in 2008 compared with the other years may be a reflection of the global financial crisis that started in 2008.

Fifteen out of sixteen IPOs went public under the main standards, while only one firm (Meyer Berger Technologies Ltd.) went public under the domestic standards. This shows that most of newly listed firms are interested in fulfilling the SIX standards for attracting not only domestic but also foreign investors. Additionally, seven out of fifteen Swiss IPO firms with available data (47 percent) had established the three recommended committees, while five companies (33 percent) had one or two board committees. Only three (20 percent) IPO firms had no established board committees at all (Table 3). This shows that newly listed companies generally tend to follow the recommendations of the Swiss code of best practice with regards to the establishment of board committees. Furthermore, 40 percent of Swiss IPOs adopted a dual leadership structure and, with just one exception, all Swiss IPOs managed to attract foreign investors ${ }^{3}$.

The majority of IPO firms experienced a reduction in their share price one year after their initial public offering (Table 3). Specifically, eight out of fourteen companies (57 percent) with available share price information had a decrease in their share price after one year of trading. However, IPO share prices did not perform significantly worse (or better) than the Swiss Market Index, which like other stock exchanges experienced the effects of the global financial crisis which started in 2008. IPO firms with the highest reduction in their share price

\footnotetext{
${ }^{3}$ Data about investing firms were collected from Thomson one banker-ownership database.
} 
are Orascom Development, Addex Pharmaceuticals and Uster Technologies. On the other hand, six out of fourteen firms experienced an increase in their share prices after the IPO event. Of particular interest are the cases of Burkhardt Compression, Santhera Pharmaceuticals and Partners Group; firms that managed to double their share price within the first year of listing (Table 3). All these three firms went public in 2006, a year that was financially favorable for new listings in Switzerland (SIX, 2010).

Table 3: IPO activity in Switzerland 2006-2008

\begin{tabular}{|c|c|c|c|c|c|c|c|c|c|}
\hline & $\begin{array}{l}\text { IPO } \\
\text { year }\end{array}$ & $\begin{array}{l}\text { Open } \\
\text { price }^{1}\end{array}$ & $\begin{array}{l}\text { Close } \\
\text { price }^{1}\end{array}$ & $\begin{array}{c}\text { Price } \\
1 \\
\text { year }^{1}\end{array}$ & $\begin{array}{c}\text { New } \\
\text { shares }\end{array}$ & Duality & $\begin{array}{c}\text { \#Board } \\
\text { compensation } \\
\text { (cash) }^{1}\end{array}$ & $\begin{array}{c}\text { Board } \\
\text { committees }\end{array}$ & $\begin{array}{l}\text { \#Foreign } \\
\text { Investors }\end{array}$ \\
\hline Addex & 2007 & 59.40 & 55.33 & 33.87 & $1,875,000$ & No & - & 2 & 10 \\
\hline Bfw & 2007 & 25.05 & 26.51 & 23.39 & $1,351,810$ & No & 166,785 & 0 & 2 \\
\hline $\begin{array}{l}\text { Burckhardt } \\
\text { Compression }\end{array}$ & 2006 & 68.06 & 74.44 & 235.42 & 735,935 & No & 222,120 & 2 & 10 \\
\hline Burkhalter & 2008 & 115.42 & 112.54 & 88.57 & 540,000 & No & $1,314,853$ & 0 & 3 \\
\hline $\begin{array}{l}\text { Goldbach } \\
\text { Media }\end{array}$ & 2007 & 33.74 & 45.79 & 41.09 & $2,163,170$ & No & - & 2 & 6 \\
\hline Gottex & 2007 & 65.06 & 65.06 & 67.75 & $8,355,029$ & Yes & - & 3 & 12 \\
\hline $\begin{array}{l}\text { Meyer } \\
\text { Burger }\end{array}$ & 2006 & - & - & - & - & - & - & - & - \\
\hline $\begin{array}{l}\text { Newave } \\
\text { Energy }\end{array}$ & 2007 & 33.72 & 44.00 & 47.16 & 625,000 & No & 634,209 & 0 & 7 \\
\hline $\begin{array}{l}\text { Orascom } \\
\text { Development }\end{array}$ & 2008 & 126.64 & 135.81 & 36.33 & $1,254,000$ & Yes & $1,097,594$ & 3 & 13 \\
\hline $\begin{array}{l}\text { Partners } \\
\text { Group }\end{array}$ & 2006 & 48.15 & 64.20 & 115.89 & 801,000 & Yes & $1,414,570$ & 3 & 28 \\
\hline Petroplus & 2006 & 52.25 & 58.02 & - & $18,000,000$ & Yes & 1,335,094 & 4 & 33 \\
\hline Saf & 2006 & 21.10 & 21.47 & 38.01 & $1,278,150$ & Yes & - & 1 & 13 \\
\hline Santhera & 2006 & 72.35 & 72.87 & 104.50 & 983,859 & No & 487432 & 3 & 7 \\
\hline U-Blox & 2007 & 46.61 & 52.16 & 23.50 & $1,250,000$ & No & 148,031 & 3 & 11 \\
\hline $\begin{array}{l}\text { Uster } \\
\text { Technologies }\end{array}$ & 2007 & 44.28 & 44.79 & 14.97 & $2,000,000$ & No & - & 3 & 7 \\
\hline $\mathbf{V z}$ & 2007 & 59.47 & 78.23 & 74.67 & - & Yes & - & 1 & 0 \\
\hline
\end{tabular}


Moreover, IPO firms had on average 1,089 employees, 686 million (USD) revenues and 390 million (USD) total assets at the time of their initial public offering (Table 4). The smallest firm in the Swiss IPO sample in terms of number of employees and total assets is SAF, while the largest one is Petroplus, an Oil \& Gas company with 7.8 billion (USD) revenues and 3.5 billion (USD) total assets. Petroplus has assets and revenues that are far higher even than the second largest Swiss IPO in this period, and raises the IPO averages illustrated in Table 4. In addition, firm performance one year prior to the offering for all IPOs was relatively high with an average ROA of 0.13 and an average ROE of 0.25 . Only three IPOs in the sample show negative profitability prior the offering with lowest ROA being -0.54 and lowest ROE being 0.71 .

Table 4: Firm Characteristics and Performance of Swiss IPOs

\begin{tabular}{|l|l|l|l|l|l|}
\hline \multicolumn{3}{|c|}{ Assets* } & Revenues* & Employees & ROA \\
Performance & ROE \\
\hline & & & & & \\
\hline Min & $8,614,282$ & $3,893,219$ & 47 & -0.54 & -0.71 \\
\hline $1^{\text {st }}$ quartile & $58,600,000$ & $12,600,070$ & 70 & 0.02 & 0.08 \\
\hline $2^{\text {nd }}$ quartile & $101,000,000$ & $98,800,070$ & 156 & 0.17 & 0.33 \\
\hline $3^{\text {rd }}$ quartile & $236,000,000$ & $106,400,008$ & 638 & 0.32 & 0.50 \\
\hline Max & $3,464,800,000$ & $7,819,700,000$ & 9,500 & 0.52 & 1.50 \\
\hline Average & $390,000,000$ & $686,000,008$ & 1089 & 0.13 & 0.25 \\
\hline N & 15 & 15 & 14 & 15 & 14 \\
\hline
\end{tabular}

As noted earlier, another feature of the Swiss governance system is the high concentration of ownership in the hands of block-holders. Recent corporate governance reforms have attempted to reduce ownership concentration and to encourage more dispersed ownership structures based on the Anglo-Saxon standards. An interesting point in the Swiss IPO sample is that ownership concentration of the Top-1 shareholder is significantly reduced from the year prior to the offering to the year after the offering. More specifically, in eleven IPOs the Top-1 shareholder owned less than 25 percent of firm's share capital (Table 5). On the other 
hand, however, in 62 percent of all IPOs with available ownership information the Top-3 shareholders owned between 25 percent and 50 percent of total shares after the first day of trading. Although this shows a slight improvement compared with ownership concentration in Table 1, further efforts to reduce the ownership concentration in Switzerland are required in order to reach the Anglo-Saxon standards. Additionally, venture capital firms and entrepreneurial families own less than 25 percent of shares after the IPO.

Table 5: Ownership in Swiss IPOs 2006-2008

\begin{tabular}{|l|c|c|c|c|c|c|c|c|}
\hline \multirow{2}{*}{} & \multicolumn{2}{|c|}{ Top 1 } & \multicolumn{2}{c|}{ Top 3 } & \multicolumn{2}{c|}{$\begin{array}{c}\text { Venture } \\
\text { Capital }\end{array}$} & \multicolumn{2}{c|}{ Family } \\
\cline { 2 - 9 } & $\begin{array}{c}\text { Pre } \\
\text { IPO }\end{array}$ & $\begin{array}{c}\text { Post } \\
\text { IPO }\end{array}$ & $\begin{array}{c}\text { Pre } \\
\text { IPO }\end{array}$ & $\begin{array}{c}\text { Post } \\
\text { IPO }\end{array}$ & $\begin{array}{c}\text { Pre } \\
\text { IPO }\end{array}$ & $\begin{array}{c}\text { Post } \\
\text { IPO }\end{array}$ & $\begin{array}{c}\text { Pre } \\
\text { IPO }\end{array}$ & $\begin{array}{c}\text { Post } \\
\text { IPO }\end{array}$ \\
\hline Less than 25\% ownership & $27 \%$ & $60 \%$ & $0 \%$ & $15 \%$ & $78 \%$ & $100 \%$ & $55 \%$ & $73 \%$ \\
\hline $\mathbf{2 5 \%}$ to 50\% ownership & $33 \%$ & $20 \%$ & $15 \%$ & $62 \%$ & $11 \%$ & $0 \%$ & $27 \%$ & $9 \%$ \\
\hline $\mathbf{5 1 \%}$ to 75\% ownership & $20 \%$ & $20 \%$ & $46 \%$ & $15 \%$ & $11 \%$ & $0 \%$ & $9 \%$ & $18 \%$ \\
\hline Over 75\% ownership & $20 \%$ & $0 \%$ & $39 \%$ & $8 \%$ & $0 \%$ & $0 \%$ & $9 \%$ & $0 \%$ \\
\hline N & 15 & 15 & 13 & 13 & 9 & 9 & 11 & 11 \\
\hline
\end{tabular}

\section{Board composition in Swiss IPOs}

As shown in Table 6, boards of directors in Swiss IPOs have on average seven members; the smallest board consists of four members while the largest one consists of ten members. The majority of directors are non-executives (63 percent) with a minimum proportion of 20 percent and a maximum of 100 percent (companies with boards consisting of only nonexecutive directors have adopted two-tier board structures ${ }^{4}$ ). Furthermore, in line with Swiss corporate governance patterns, female directors are relatively few (average female participation is 5 percent), while the average age of board members is 52 years old. Another interesting characteristic of Swiss IPO boards is the educational qualification level of directors. As Table 6 shows, the average proportion of directors with a PhD degree is high (27 percent), while many others hold at least an MBA or Master of Science (MSc) degree (13

\footnotetext{
${ }^{4}$ A two-tier board of directors in the Swiss context is more comparable to a board of directors in the AngloAmerican context than a supervisory board in the German context. In Switzerland the term "supervisory board" is not typically used but rather considered as a German institution. The executive board is considered as the top management team.
} 
percent and 26 percent respectively). The educational level of directors has been characterized as a signal of firm's reputation (Certo, 2003) and, faced with uncertainty Swiss IPOs, appear to communicate the competence level of the people involved in the company to potential investors.

Table 6: Board Characteristics of Swiss IPOs

\begin{tabular}{|l|l|l|l|l|l|l|l|l|}
\hline & $\begin{array}{l}\text { Non } \\
\text { executive } \\
\text { directors }\end{array}$ & $\begin{array}{l}\text { Female } \\
\text { directors }\end{array}$ & $\begin{array}{l}\text { Board } \\
\text { Average } \\
\text { Age }\end{array}$ & $\begin{array}{l}\text { Board } \\
\text { Size }\end{array}$ & $\begin{array}{l}\text { Highest } \\
\text { degree } \\
\text { PhD }\end{array}$ & $\begin{array}{l}\text { Highest } \\
\text { Degree } \\
\text { MBA }\end{array}$ & $\begin{array}{l}\text { Highest } \\
\text { Degree } \\
\text { Master }\end{array}$ & $\begin{array}{l}\text { Highest } \\
\text { Degree } \\
\text { Bachelor }\end{array}$ \\
\hline Min & $20 \%$ & $0 \%$ & 45 & 4 & $0 \%$ & $0 \%$ & $5 \%$ & $15 \%$ \\
\hline Max & $100 \%$ & $20 \%$ & 60 & 10 & $60 \%$ & $50 \%$ & $67 \%$ & $62 \%$ \\
\hline Average & $63 \%$ & $5 \%$ & 52 & 7 & $27 \%$ & $13 \%$ & $26 \%$ & $26 \%$ \\
\hline $\mathbf{N}$ & 15 & 15 & 15 & 15 & 15 & 15 & 15 & 15 \\
\hline
\end{tabular}

\section{Demographic Diversity in Swiss IPO Boards and TMTs}

Researchers have argued that diversity in the boardroom brings more information processing abilities (Richard and Shelor, 2002) and higher quality of executive monitoring (Hillman and Dalziel, 2003). Investors may consider board and TMT diversity as a positive signal for IPOs' likelihood of success (Certo, 2003). Nationality and educational level diversity was measured using Blau's (1977) index, calculated as $1-\Sigma \mathrm{pi}^{2}$, where p represents the proportion of board members in the $\mathrm{i}^{\text {th }}$ nationality/educational category (Elron, 1997; Harrison and Klein, 2007; Tihanyi, et al., 2000). Since age is an interval variable, age diversity was calculated by dividing the standard deviation by the mean of age for each board and TMT (Tihanyi et al., 2000; Zimmerman, 2008). High scores indicate high age, educational level and nationality diversity.

As mentioned earlier, the Swiss code recommends that boards of directors and management teams of Swiss companies listed under the main standards should consist of members who have extended international experiences and/or who are foreign nationals. As Table 7 illustrates, the average nationality diversity in Swiss IPOs is relatively high with a mean score of 0.41 diversity index. This indicates that newly listed firms tend to follow this recommendation. Moreover, educational level diversity of IPO boards is also high with an 
average diversity index of 0.59 , while age diversity is lower. Similar to boards, TMT nationality and educational diversity of Swiss IPOs is relatively high (0.31 and 0.12 respectively) while age TMT diversity remains lower. In general, TMTs of Swiss IPOs tend to be less diverse in the three demographic attributes than boards of directors.

Table 7: Board and top management team diversity in Swiss IPOs

\begin{tabular}{|l|l|l|l|l|l|l|}
\hline & $\begin{array}{l}\text { Board } \\
\text { nationality } \\
\text { diversity }\end{array}$ & $\begin{array}{l}\text { Board } \\
\text { age } \\
\text { diversity }\end{array}$ & $\begin{array}{l}\text { Board } \\
\text { educational } \\
\text { diversity }\end{array}$ & $\begin{array}{l}\text { TMT } \\
\text { nationality } \\
\text { diversity }\end{array}$ & $\begin{array}{l}\text { TMT } \\
\text { age } \\
\text { diversity }\end{array}$ & $\begin{array}{l}\text { TMT } \\
\text { educational } \\
\text { diversity }\end{array}$ \\
\hline Min & 0 & 0.20 & 0.38 & 0 & 0.03 & 0.32 \\
\hline 1 st percentile & 0 & 0.12 & 0.53 & 0 & 0.08 & 0.38 \\
\hline $2^{\text {nd }}$ percentile & 0.50 & 0.14 & 0.61 & 0.28 & 0.11 & 0.55 \\
\hline $3^{\text {rd }}$ percentile & 0.76 & 0.16 & 0.66 & 0.56 & 0.17 & 0.65 \\
\hline Max & 0.82 & 0.24 & 0.80 & 0.78 & 0.19 & 0.85 \\
\hline Average & 0.41 & 0.14 & 0.59 & 0.31 & 0.12 & 0.55 \\
\hline $\mathrm{N}$ & 15 & 14 & 15 & 10 & 14 & 15 \\
\hline
\end{tabular}

\section{Description of a Swiss IPO: Burkhalter Group}

The firm before the IPO

Burkhalter Group, formerly "Ernst-Burkhalter AG", is an electrical installation company founded in 1959 in Zurich. The company provides electrical installation services to residential, industrial and commercial buildings. The initially small and locally active electrical installation business grew in the next three decades as an active group of companies across the four language regions of Switzerland. In 1987, the company was sold to Zellweger Luwa AG, an electrical equipment company, while in 1997 Burkhalter Holding AG became independent again. Until the year-end 2000, almost 40 percent of the company's capital was owned by employees and initial owners, while one year later the company's capital and the number of owners increased. In the year before the IPO (year-end 2007) the company generated 363 million (USD) revenues, had 252 million (USD) assets, 2,520 full-time employees and operated in 84 locations throughout Switzerland. Three major shareholders were holding 43 percent of the total capital. The company's share capital before the offering 
was 573,942 shares, and three major shareholders were holding 43 percent of this capital. Six months prior the offering, Burkhalter's former CEO Tarzisius Caviezel resigned and was replaced by Marco Syfrig who became the new CEO and a member of the board of directors. At the end of IPO year Marco Syfrig received an annual cash remuneration of 403,550 (USD). In addition, two board members stepped down during the same year, resulting in a total board size of five directors. At the year-end 2007, the directors owned 36 percent of the firm's capital and received 1.31 million (USD) total annual compensation.

\section{The offer}

Burkhalter Group went public in June 2008 under the main SIX standards. Zurich Cantonal Bank was the responsible agent of Burkhalter Group's IPO. During the offer, the company doubled its share capital from 9,463,287 to $18,366,807$ (USD) through the issue of 540,000 registered shares with a nominal value of 16 (USD) and an opening price of 115 (USD) for each offered share. The total number of shares after the offering was 1,113,942 while 42,073 of them were hold by the company and its subsidiaries. The majority of shares were allocated to domestic institutional investors, while the board possessed 247,151 shares. Concerning ownership concentration, the Top- 1 shareholder had 10 percent and the Top-3 shareholders had 21.5 percent of the share capital. Burkhalter's initial public offering was not supported by any venture capital firm or business angel. The first opening price slightly dropped at the first day of trading (115 USD and 112 USD first opening and first closing price respectively). At the time of the offering, the firm was expecting to compensate its investors with a total amount of 60,000,000 IPO proceeds (USD).

\section{The firm after the offering}

One year after the offering, Burkhalter's share price dropped from 112 (first closing price) to 89 (USD). An important factor of the drop in Burkhalter's share price is the total drop of the SIX market index due to the financial crisis in 2008. However, two years after the IPO (June 2010) Burkhalter's share price increased to 136 (USD), a price that is even higher than its first opening price. During the first year of listing the board consisted of five members when two of them were non-executives (mixed board structure) and one was independent director. In addition, the top management team consisted of three members holding the positions of CEO, COO and CFO. 
Despite the Swiss Code recommendations for establishing board committees, the firm had no established board committees in 2008. For the adequate internal control of the company the board used some monitoring tools such as: a) monthly reporting of management performance, b) quarterly statements, and c) approval of annual budget and group's strategy twice a year. In addition, the proportion of share ownership of the Top-3 shareholders increased from 21.5 percent at the time of the offering to 30.8 percent one year after and reached the proportion of 30.1 percent at the year-end 2009. This shows that although Burkhalter Group had a lower rate of ownership concentration than the average in Swiss IPOs at the time of its initial listing, it reached the average ownership concentration within the first year after the offering.

Finally, all members of both board and executive management were Swiss nationals, a feature that fits well with the firm's domestic strategy. However, the company became listed under the main standards with the intention to attract foreign institutional investors. The number of foreign investors during the first quarter after the offering was particularly low compared with other firms in the Swiss IPO sample (only three investors). This small number of foreign investors can be a reflection of Burkhalter's high degree of TMT and board nationality homogeneity. In 2008 Burkhalter group acquired Electra Buin SA and two other smaller companies in Switzerland. Burkhalter Group aims to further expand its operations through M\&A activities within the country. As Burkhalter's CEO, Marco Syfrig claimed: "By continuing our acquisition strategy and constantly strengthening our risk management procedures we will be able to more than compensate for any organic sales decline at Group level" (Burkhalter, Annual Report, 2008).

\section{CONCLUSION}

The aim of this study was to describe the current state of corporate governance in Switzerland and to consider whether newly listed firms tend to comply with the recent corporate governance reforms. Descriptive statistics of all Swiss IPOs between 2006 and 2008 show that a high proportion of firm shares in most of IPOs are owned by three major shareholders immediately after the initial public offering. Despite recent efforts to encourage more dispersed ownership, the ownership structure of IPO firms still remains concentrated. This is clear in the described IPO sample where, in most of cases, the top three shareholders possessed a high percent of the total shares (above 25 percent). On the other hand, Swiss IPOs 
have tended to follow the recommendations of the Swiss code concerning the composition of the board of directors and the establishment of board committees. More specifically, most Swiss IPO boards consist of a majority of non-executive directors, have on average seven members, the majority of whom are highly educated, and have established the three recommended board committees. However, there are some other governance features that need to be considered, such as the low representation of female directors and the dualistic leadership structure that some IPOs tend to adopt.

The paradoxes identified in the beginning of this chapter will probably live on in the near future. First, high share ownership concentration in Switzerland may have served as a reason for the comparatively low number of Swiss IPOs: Swiss entrepreneurial ventures have other means to attract investors than via IPOs only. Indeed, Swiss IPOs do not appear to significantly contribute to a reduction of ownership concentration ratios. Second, although nationality diversity levels at Swiss IPO TMT and boards are exceptionally high, the presence of foreign investors seems modest. It is possible that foreign IPO TMT or board members have studied or lived in Switzerland for some time, and do not act as a force of change in the Swiss corporate governance system. In short, there are tendencies of the Swiss corporate governance system to converge to more Anglo-American or global standards. However, findings presented in this chapter suggest that Swiss IPOs, as nascent corporate governance arrangements, do not serve as a force of such convergence. The convergence process may take longer than some think. 


\section{REFERENCES}

Burkhalter Group, Annual Report 2008. Available from: www.burkhalter.ch/upload /public/0/24/BURKH39863E_Portraet_GzD_def.pdf Accessed on: 20/12/2010.

Blau, Peter, M. 1977. Inequality and Heterogeneity, Glencoe, IL: Free Press.

Carpenter, Mason, Pollock, Timothy, and Leary Myleen. 2003. 'Testing a model of reasoned risk taking: Governance, the experience of principal and agents, and global strategy in hightechnology IPO firms’, Strategic Management Journal, 24, 9, 802-20.

Certo, Trevis, S. 2003. 'Influencing initial public offering investors with prestige: Signaling with board structures', Academy of Management Review, 28, 3, 432-47.

Code of Obligations. Available from: www.admin.ch/ch/d/sr/2/220.de.pdf Accessed on: $26 / 12 / 2010$

Deloitte, (2009). Swiss Stock Exchange Analysis. Available from: www.deloitte.com/assets/DcomSwitzerland/Local\%20Assets/Documents/SwissStockExchang eAnalysisQ1_2009.pdf, Accessed on: 26/12/2010

Deloitte, (2010). Swiss Stock Exchange Analysis. Available from: www.deloitte.com/view/en_CH/ch/services/corporatefinance/d19bf6310a028210VgnVCM10 0000ba42f00aRCRD.htm, Accessed on: 26/12/2010

Economiesuisse: 2007, Swiss code of best practice for corporate governance, Available from: www.economiesuisse.ch/web/de/pdf\%20download\%20files/pospap govern_20080221_en.pdf Accessed on: 26/12/2010.

_swiss-code_corp-

Elron, Efrat. 1997. 'Top management teams within multinational corporations: Effects of cultural heterogeneity’, Leadership Quarterly, 8, 4, 393-412.

Ernst \& Young, 2008. IPO insights: SWX Swiss exchange. Available from: www2.eycom.ch/publications/items/2008_ipo_insights/2008_ey_ipo_insights_swx.pdf, Accessed on 20/12/2010.

Paleari, Stephano, Piazzalunga, Redondi, Trabucchi, Daniele, Renato, Fabio, and Vismara Silvio. 2006. Academic EurIPO Factbook Universoft: Bergamo-Italy.

Harrison, David, A., and Klein, Katherine, J. 2007. 'What's the difference? Diversity constructs as separation, variety or disparity in organizations', Academy of Management Review, 32, 4, 1199-1228.

Hillman, Amy, J., and Dalziel Thomas. 2003. 'Boards of directors and firm performance: Integrating agency and resource dependence perspectives', Academy of Management Review, 28, 3, 383-96.

$\mathrm{Hu}$, Yan. 2009. 'The adoption of board committees in Swiss listed firms'. PhD thesis, Research Institute for international management, St. Gallen, Switzerland. 
International Monetary Fund (IMF). 2007. Switzerland financial sector assessment program, Available from: www.imf.org/external/pubs/ft/scr/2007/cr07202.pdf, Accessed on: 20/12/2010.

Keller, Hans Ulrich. 2003. 'The determinants and effects of interlocking directorships and board composition: An empirical analysis of corporate governance in Switzerland'. $\mathrm{PhD}$ thesis, Research Institute for international management, St. Gallen, Switzerland.

Mach, Andre, G., Schnyder, Gerhard, Lupold, Martin, and David Thomas. 2007. 'Transformation of self regulation and new public regulations in the field of Swiss corporate governance (1985-2002)', World Political Science Review, 3, 2, 1-30.

OECD 2006. 'Corporate governance of non-listed companies in emerging markets', Available from: www.oecd.org/dataoecd/48/11/37190767.pdf, Accessed on: 20/12/2010.

Pedrazzini, Mario 1998. Gesellschaftsrechtliche Entscheide, eine Sammlung für das Studium: Stampfli, Bern.

Richard, Orlando, and Shelor Roger M. 2002. 'Linking top management team age heterogeneity to firm performance: Juxtaposing two mid-range theories', International Journal of Human Resource Management, 13, 6, 11-23.

Ruigrok, Winfried, and Canepa Ancillo. 2005. The Impact of Audit Committees on Swiss Companies. Ernst\&Young/University of St Gallen Available from: www.fim.unisg.ch/org/fim/web.nsf/SysWebRessources/The+Audit+Committee+Impact+on+ Swiss+Companies/\$FILE/The+Audit+Committee+Impact+on+Swiss+companies.pdf, Accessed on: 26/12/2010.

Ruigrok, Winfried, Peck, Simon, and Keller, Hans Ulrich. 2006. 'Board characteristics and involvement in strategic decision making: Evidence from Swiss companies', Journal of Management Studies, 45, 5, 1201-1226

Ruigrok, Winfried, Peck, Simon, and Tacheva, Sabina. 2007. 'Nationality and gender diversity on Swiss corporate boards', Corporate Governance: An International Review, 15, 4, 546-57.

Schleiffer, Patrick, and von Planta, Andreas. 2009. "Switzerland" in The International Comparative Legal Guide to: Corporate Governance 2009, London: Global Legal Group. Available from: www.iclg.co.uk/khadmin/Publications/pdf/2958.pdf, Accessed on 20/12/2010.

Schweizer, Markus, 2006. "Recent corporate governance reforms in Switzerland," Switzerland: Economiesuisse, Available from: www.eycom.ch/library/items/200603_ cogo/en.pdf, Accessed on 26/12/2010.

SIX 2010. Available from: www.six-swiss-exchange.com/index.html, Accessed on 20/12/2010.

SIX Listing Rules 2006. Available from: http://www.six-swissexchange .com/news/new_admissions_en.html, Accessed on 20/12/2010. 
Tihanyi, Lazlo, Ellstrand, Alan E., Daily, Cathline, M., and Dalton Dan R. 2000. 'Composition of the top management team and firm international diversification', Journal of Management, 26, 6, 1157-77.

US Commercial Service, 2009. Doing Business in Switzerland 2009, Available from: www.buyusainfo.net/docs/x_5002686.pdf Accessed on 20/12/2010.

World Bank, 2010. Doing Business in Switzerland 2011, Available from: www.doingbusiness.org/ /media/fpdkm/doing\%20business/documents/profiles/country/db11/ che.pdf Accessed on 20/12/2010.

World Economic Forum, 2010. The Global competitiveness report. Available from: www3.weforum.org/docs/WEF_GlobalCompetitivenessReport_2010-11.pdf, Accessed on: 24/12/2010.

Zimmerman, Monica, A. 2008. 'The influence of top management team heterogeneity on the capital raised through an initial public offering', Entrepreneurship Theory and Practice, 32, 3, 391-414. 